is often confused with $N$. polita. Due to the striking similarity between $N$. maxima and $N$. polita, it may be possible that the real $N$. maxima was identified as $N$. polita, which consequently led to misidentification of $N$. nigrita as $N$. maxima. Interestingly, the distribution of $N$. semirugosa is restricted to the western Pacific from Queensland, Australia to the Solomon Islands ${ }^{1}$. Therefore, $N$. nigrita clearly stands out in this region without any confusion. However, now as we resolve this problem, it is also important to provide details of $N$. polita and $N$. undata which may be confused with $N$. nigrita and $N$. maxima. Table 1 provides the detailed key characters, discriminating features and distribution of the abovementioned species.

The distribution of $N$. nigrita ranges from Thailand, Indonesia, westward through Sri Lanka, Maldives and Madagascar. However, this species has never been documented from the Indian coast due to its misidentification as $N$. maxima. $N$. nigrita shares a great degree of similarity with $N$. semirugosa, which is restricted to the western Pacific. However, with this report we resolve the confusion of $N$. nigrita and $N$. maxima; simultaneously, the occurrence of this species also extends the geographical range of $N$. nigrita on the Indian coast. In order to avoid future confusion, we have also provided a comparative account of $N$. maxima, $N$. polita and $N$. undata which are similar to each other and have been documented from the Indian coast.

1. Eichhorst, T. E., Neritidae of the World, Vol. 1, Conch Books, Hackenheim, Germany, 2016, p. 694

2. Tan, S. K. and Clements, R., Taxonomy and distribution of the Neritidae (Mollusca: Gastropoda) in Singapore. Zool. Stud., 2008, 47(4), 481-494.

3. Subba Rao, N. V., Indian Seashells: Polyplacophora and Gastropoda. Rec. Zool. Surv. India, 2003, Occasional paper 192.

4. Ganesh, T., Sansita, K. P., Kasi Vishweshwara Rao, Y., Surya Rao, K. V. and Raman, A. V., A new record of Nerita (Ritena) maxima, Gmelin 1971 (Mollusca: Gastropoda: Neritidae) from the west coast of India (Arabian Sea). J. Conchol., 2005, 38(5), 605-606.

ACKNOWLEDGEMENTS. We thank Pondicherry University, Port Blair for providing necessary facilities to carry out this work and providing a fellowship to V.P. We also thank Prof. Henk Dekker (VU University, Amsterdam) for help on the information of Nerita nigrita and Dr Hamish G. Spencer (University of Otago), New Zealand for providing the necessary literature.

Received 23 July 2018; revised accepted 15 November 2018

doi: $10.18520 / \mathrm{cs} / \mathrm{v} 116 / \mathrm{i} 5 / 828-831$

\section{Rice straw biomass to high energy yield biocoal by torrefaction: Indian perspective}

\author{
S. R. Dhakate*, Abhishek K. Pathak, \\ Prateek Jain, Mandeep Singh, B. P. Singh, \\ K. M. Subhedar, S. S. Sharda and R. K. Seth \\ CSIR-National Physical Laboratory, \\ Dr K.S. Krishnan Marg, New Delhi 110 012, India, and \\ AcSIR, National Physical Laboratory, New Delhi 110 012, India
}

India is an agriculture based country and generates more than 600 million tonnes of biomass waste from different crops and produces 140 million tonnes of rice straw alone annually. To dispose the rice straw for making field ready for next crop, farmers are burning it in the fields. Burning of rice straw in agriculture fields poses lot of environmental, health and economic issues in various parts of the country. On one hand, rice straw is a good source of renewable energy but on the other hand it has some inherent problems. Therefore, to mitigate problems due to the burning of rice straw, in this study, an effort is made to convert rice straw into an useful product by torrefaction process, i.e. biocoal. The biocoal which has the calorific value equivalent to that of bituminous coal is used in thermal power plants. By optimizing the processing parameters of torrefaction process, desired calorific value of torrefied product has been archived. The $10 \%$ use of torrefied product with coal can consume 140 million tonnes of rice straw and as a consequence, it reduces the consumption of fossil fuels. This can greatly solve problems arising due to burning of rice straw and reduce greenhouse gas emission significantly.

Keywords: Calorific value, energy yield, pelletization, rice straw, torrefaction.

Climate change and the inevitable depletion of fossil fuel reserves are among the major challenges the humanity is facing in the 21 st century, which has led to a boom in research related to alternative energy sources and reducing greenhouse gas (GHG) emissions. Agricultural biomass rice straw, is a secondary lignocellulosic biomass abundantly available in many parts of the world and around 731 million tonnes are produced per year globally ${ }^{1}$. Among the different countries, Asian countries produce 667 million tonnes of rice straw and India alone produces $\sim 140$ million tonnes ${ }^{2}$ annually. In India, some of the rice straw used as roofing material, animal feed, fuel and packing material, while the rest is disposed by burning in the agriculture field itself. Burning agro-residues in the field is considered a cheap and easy way of disposal to

*For correspondence. (e-mail: dhakate@nplindia.org) 
prepare the fields for next crop ${ }^{3}$. Burning of rice straw in the field produces ash, which is used as a soil fertilizer. However, it has low concentration of nitrogen and phosphorus, along with occasional presence of some heavy metals which have a negative effect on soil and, therefore, reduce crop productivity ${ }^{4}$. Rice straw burning also produces significant visible smoke which can spread over larger area, consequently affecting large population with various problems. Burning of one tonne of rice straw emits $3.7 \mathrm{~kg}$ particulate matter, $1.0 \mathrm{~kg}$ volatile organic compounds, $3.1 \mathrm{~kg} \mathrm{NO}, 0.7 \mathrm{~kg} \mathrm{SO}_{x}$ and $34.7 \mathrm{~kg}$ of carbon monoxide ${ }^{5}$. These gaseous emissions are responsible for various health risks like asthma, bronchitis, decreased lung function and also increase fog incidences even in distant cities ${ }^{6}$.

Rice straw biomass is mainly composed of cellulose, hemicellulose, lignin and ash content. It is an organic matter in which solar energy is stored in the chemical bonds of cellulose, hemicellulose and lignin molecule. When these bonds between adjacent carbon, hydrogen and oxygen atoms are broken, stored chemical energy is released. This is recognized as a renewable source for energy production. The combustion of biomass produces less harmful gas emissions compared to conventional fossil fuels. In addition, it can reduce atmospheric carbon dioxide $\left(\mathrm{CO}_{2}\right)$ emission. This is due to the balance of net $\mathrm{CO}_{2}$, since $\mathrm{CO}_{2}$ which is released from the burning of bio fuel is proportional to the $\mathrm{CO}_{2}$ that is fixed from the atmosphere by plants during photosynthesis ${ }^{7}$.

However, there are inherent problems with raw rice straw compared to fossil fuel resources, i.e. low bulk density, high moisture content, hydrophilic nature, and low gross calorific value (GCV) which render it difficult to utilize on a large scale ${ }^{8}$. These limitations seriously impact logistics and final energy efficiency. High moisture in rice straw is one of the primary challenges as it reduces the efficiency of the process and increases fuel production costs, leads to natural decomposition, loss of quality and storage issues such as off-gas emissions 9 . These collective attributes make rice straw an unacceptable renewable source for energy.

To overcome these challenges and to make rice straw suitable for energy applications, some form of pre-treatment is required which alters biomass physical and chemical properties ${ }^{10}$. There are different thermochemical (combustion, gasification, pyrolysis and esterification) and biological (anaerobic, digestion and fermentation) processes. On the other hand, torrefaction is a thermal process to convert biomass into a coal-like material, i.e. biocoal. This biocoal can replace fossil fuels in cookstoves, rural industries, industrial boiler and furnaces which can significantly reduce pollution and in thermal plants by co-firing with coal ${ }^{11,12}$. Torrefaction is defined as mild pyrolysis (temperature between $200^{\circ} \mathrm{C}$ and $350^{\circ} \mathrm{C}$ ) of biomass in protective atmosphere which alters the physical and chemical composition of rice straw. Physical changes mainly consist of reduction in biomass volume, density increment, increased brittle character and easy grinding while the chemical changes include increased hydrophobic effect, increment in carbon content and energy density. Advantages of torrefaction over other processes include cost effectiveness, high GCV and additional shelf life of biomass. However, in biomass technology group's (BTGs) torrefaction process, the heat required is generated by combustion of vapours that are released in the process. For this purpose, the gases are directed to a dedicated combustion chamber, in which combustion takes place at sufficiently high temperatures. The hot flow of gas from combustion is forced along the reactor wall to indirectly heat the biomass. Depending on the feedstock and required product quality, excess heat can be generated, which can be used for drying purposes or electricity production.

In India, majority of the thermal power plants utilize coal as a fuel for power generation. In 2017-18, $\sim 200 \mathrm{GW}$ power was generated by using coal, which is around $57 \%$ of the total power generated by thermal power plants ${ }^{13}$. While in the northern part of the country, particularly in paddy growing states like Punjab, Haryana, Uttar Pradesh, Jammu Kashmir and Uttarakhand, farmers are burning rice straw in the fields for sowing the next crop due to many reasons. At present, they are not paid for the crop stubble and as a result they burn it. Once farmers get monetary incentive for the waste, burning can be stopped in the fields and it can be used as a source of renewable energy and the country can become self-reliant for energy generation.

In the present study, efforts are made to convert rice straw in to useful alternative fuel, such as biocoal for cofiring in thermal power plant so that it can reduce not only the consumption of fossil fuels, but also reduce environmental pollution and greenhouse effect ${ }^{11}$.

Rice straw for this study was collected from the state of Haryana, India. The rice straw procured from the field was chopped into small pieces of $1-2 \mathrm{~cm}$ length. Torrefaction was carried out at different temperatures, i.e. $250^{\circ} \mathrm{C}, 300^{\circ} \mathrm{C}, 350^{\circ} \mathrm{C}, 400^{\circ} \mathrm{C}$ with an isothermal time of $30 \mathrm{~min}$ at particular temperature in presence of nitrogen atmosphere in a laboratory scale set up (Figure 1). The laboratory scale set up consists of stainless steel (SS) reactor inside a resistive heating jacket equipped with proportional integral derivative (PID) controller and temperature indicator. The SS reactor was heated with a heater, biomass inside the reactor was heated through contact with reactor walls and the material inside the reactor was agitated by stirrer for uniform heating of biomass. The temperature of biomass inside the reactor was measured by thermocouple. A condenser was attached to collect the condensable and non-condensable reaction products at the top end of the SS reactor. The chopped rice straw of $200 \mathrm{~g}$ was kept in the SS reactor and the temperature of the reactor was increased by $10^{\circ} \mathrm{C} / \mathrm{min}$ up to torrefaction temperature. During torrefaction, the 
released condensable and non-condensable reaction products were collected by the condenser. The reactor was cooled by normal process. The torrefied product was designated as $\mathrm{T} 1, \mathrm{~T} 2, \mathrm{~T} 3, \mathrm{~T} 4$ and $\mathrm{T} 5$ for torrefaction temperatures $0^{\circ} \mathrm{C}, 250^{\circ} \mathrm{C}, 300^{\circ} \mathrm{C}, 350^{\circ} \mathrm{C}$ and $400^{\circ} \mathrm{C}$ respectively.

The moisture content in rice straw and different torrefied mass was calculated according to ASTM D2867-17. The pyrolysis characteristics of the rice straw and torrefied products were studied using a thermogravimetric analyser (TGA, Mettler Toledo). The TGA was carried out in the range of $30-1000^{\circ} \mathrm{C}$ at $10^{\circ} \mathrm{C} / \mathrm{min}$ in nitrogen atmosphere. From TGA data, proximate analysis was done in accordance with standard ASTM E870-82 procedure. The reaction that takes place is indicated by derivative of thermogravimetric (DTG), which gives information of the thermal degradation of hemicellulose, cellulose and lignin. Bulk density of rice straw powder and torrefied products was measured using specific gravity bottle of constant volume $10 \mathrm{ml}$. The GCV of rice straw and different torrefied products was measured by Isoperibol automatic bomb calorimeter (model IP-1, Advance) according to ASTM D5468-02. The mass and energy yield were calculated by the equation used by

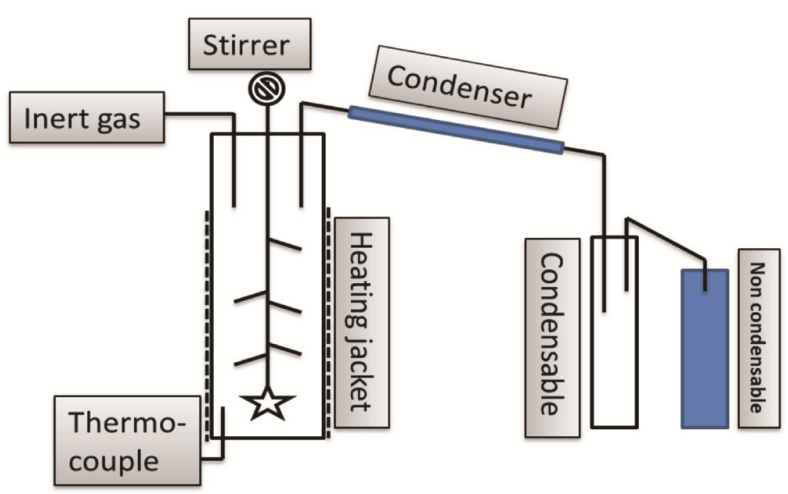

Figure 1. Schematic batch process setup of torrefaction with $200 \mathrm{~g}$ biomass capacity.
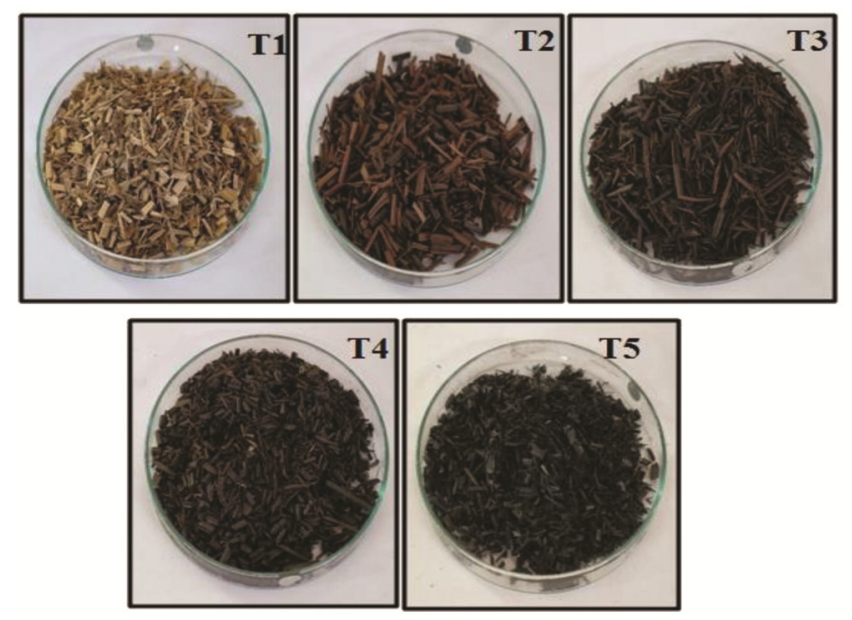

Figure 2. Morphology of torrefied rice straw product.
Bridgeman et al. ${ }^{14}$. The morphology of raw rice straw and torrefied products was observed by scanning electron microscope (Carl Zeiss EVO MA10 Variable Pressure SEM). The neat rice straw and torrefied products were characterized by using X-ray diffractometer (D-8 Advanced Bruker powder X-ray diffractometer) using $\mathrm{CuK} \alpha$ radiation $(\lambda=1.5418 \AA)$ at a scanning rate of $2 \% \mathrm{~min}$ with voltage $40 \mathrm{kV}$ with a current of $40 \mathrm{~mA}$ and within the range of $2 \theta=5^{\circ}-60^{\circ}$.

Figure 2 shows the image of torrefied rice straw products after torrefaction at different temperatures in protective atmosphere. Torrefaction above $150^{\circ} \mathrm{C}$ is called as reactive drying range and in this breakage of hydrogen and carbon bonds take place, resulting in the emission of lipophilic extractives and compounds due to thermal degradation of biomass. In the temperature range 200$250^{\circ} \mathrm{C}$, structural deformity occurs and as a result rice straw loses its ability to regain its original structure if rewetted. The colour of rice straw changes from light brown to dark brown (Figure 2, T2 and T3). The colour change is a good means of describing the degree of torrefaction. With increasing torrefaction temperature, i.e. $>300^{\circ} \mathrm{C}$, destructive drying takes place, resulting in carbonization and devolatilization of rice straw. This temperature represents the torrefaction process limit and as a consequence, disruption of most of the intra and intermolecular hydrogen bonds, $\mathrm{C}-\mathrm{C}$ and $\mathrm{C}-\mathrm{O}$ bonds, resulting in the formation of hydrophilic extractives, destroyed cell structure, loss of fibrous nature and becoming brittle. The torrefied products turn from brown to black (sample T3T5), which can be mainly attributed to chemical compositional changes.

The TGA and DTG curves of rice straw powder and torrefied products are depicted in Figure 3. The pyrolysis behaviour of rice straw (T1) and torrefied product (T2T5) reveals that there is a three-stage thermal degradation and decomposition. The first stage is drying of biomass followed by degradation of hemicellulose and cellulose while in final stage, decomposition of lignin occurs, which is directly related to torrefaction temperature. During the initial heating between temperatures $150^{\circ} \mathrm{C}$ and $200^{\circ} \mathrm{C}$, dehydration of lignocellulosic rice straw takes place due to chemical reactions through a thermocondensation process and results in the formation of some content of carbon dioxide ${ }^{15}$. Above $300^{\circ} \mathrm{C}$, the reaction is entirely exothermic, and gas production increases, resulting in the formation of $\mathrm{CO}$, hydrocarbons like phenols and cresols, and other heavier products. This led to extensive devolatilization of biomass due to the initiation of pyrolysis process ${ }^{16}$. As a result, there is a higher weight loss in case of sample $\mathrm{T} 1$ (rice straw) above $300^{\circ} \mathrm{C}$.

The thermal decomposition of rice straw mainly occurred in second stage due to more exothermic reactions between temperatures $210^{\circ} \mathrm{C}$ and $410^{\circ} \mathrm{C}$. In case of sample $\mathrm{T} 1$, DTG peaks at around $290^{\circ} \mathrm{C}$ and $327^{\circ} \mathrm{C}$ is due to the thermal degradation of hemicellulose and cellulose which 
is attributed to the release of volatile matter. In the third stage, a peak between $440^{\circ} \mathrm{C}$ and $480^{\circ} \mathrm{C}$ is that of lignin. After torrefaction at $250^{\circ} \mathrm{C}$ (sample T2), thermal decomposition temperature range of second stage increases to $230-490^{\circ} \mathrm{C}$ and DTG peak of hemicellulose disappears due to the depletion of large fraction of hemicellulose. While the peak intensity of cellulose peak at $\sim 329^{\circ} \mathrm{C}$ is slightly higher which reveals that more cellulose content is available in the torrefied product at $250^{\circ} \mathrm{C}$ (ref. 17). Further increasing the torrefaction temperature to $300^{\circ} \mathrm{C}$, $350^{\circ} \mathrm{C}$ and $400^{\circ} \mathrm{C}$, there is continuous reduction in thermal degradation temperature of rice straw in the same pattern (Figure $3 b$ ). During torrefaction, hemicellulose is the main component of biomass that decomposes through depolymerization, volatilization and carbonization reactions $^{18}$.

The DTG curve of sample T3 shows significant decrease in the intensity of cellulose peak, this represents the depletion in cellulose content in torrefied rice straw at $300^{\circ} \mathrm{C}$ and peak around $460^{\circ} \mathrm{C}$ is slightly intense as compared to sample T2, which is of lignin due to the decrease
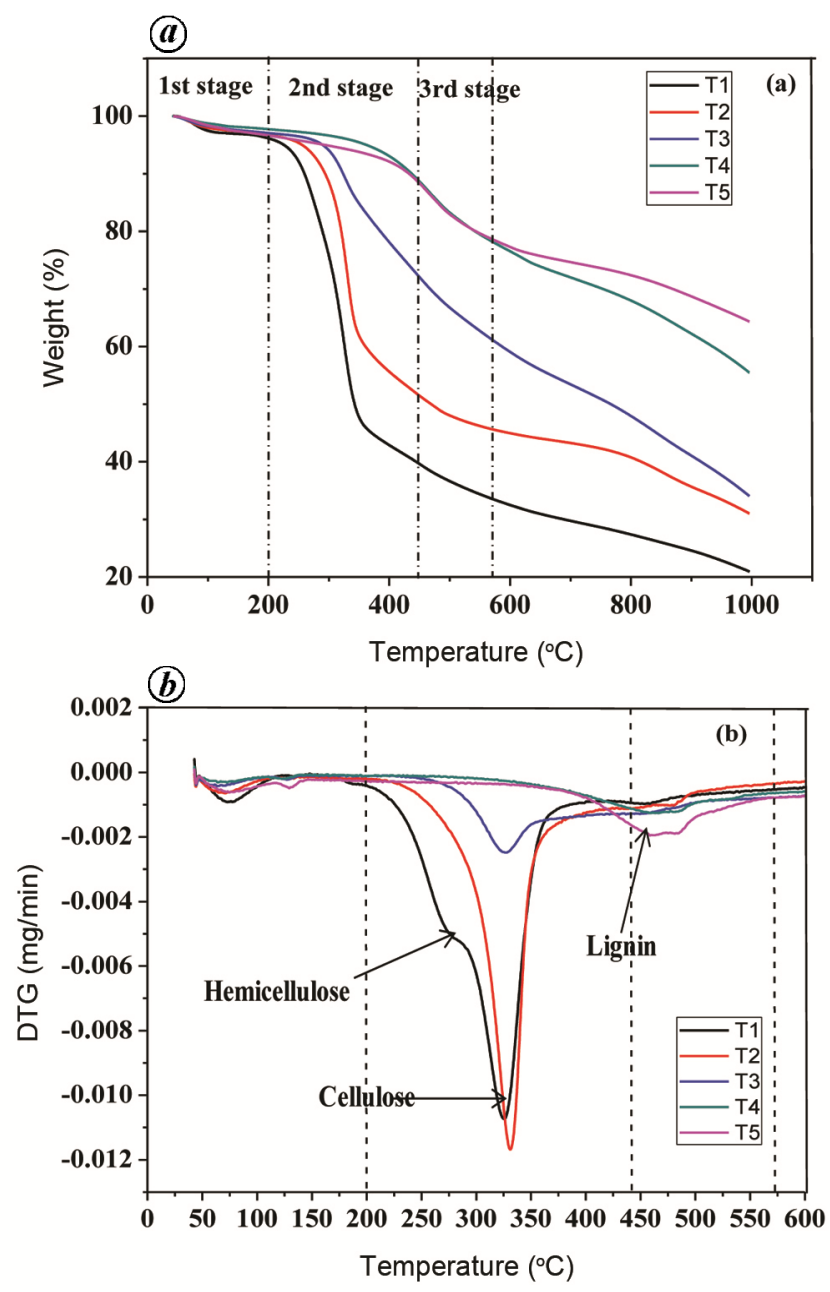

Figure 3. (a) TGA and (b) DTG curve of raw rice straw and torrefied product. in the peak intensity of cellulose. While at torrefaction temperature $350^{\circ} \mathrm{C}$ and $400^{\circ} \mathrm{C}$, the peak of hemicellulose and cellulose almost disappeared which suggest that there is complete degradation of both hemicellulose and cellulose in the torrefied rice straw and only lignin is present partially $^{19}$.

Kongkaew et $a .^{20}$ also reported kinetics of rice straw pyrolysis by TGA in which main emphasis was on the effect of heating rate on TG and DTG behaviour of rice straw. With increasing heating rate, TG and DTG peaks shifted to higher temperature. While at the same time and in the same temperature region a higher heating rate has a short reaction time and therefore the temperature needed for the sample to decompose is also higher.

Morphology of the untreated rice straw and torrefied product was analysed by SEM (Figure 4). In Figure 4, images $\mathrm{T} 1$ and $\mathrm{T} 2$ of rice straw show organized structure of cellulosic fibres with silica globule evolved out with torrefaction temperature. With increase in the torrefaction temperature, organized structure of the rice straw changes but not completely destroyed at temperature $250^{\circ} \mathrm{C}$ (T2). However, there is loss of moisture and as a result shrinkage in the rice straw. Increase in the torrefaction temperature $>250^{\circ} \mathrm{C}$ results in the decomposition of hemicellulose and lignin with extensive evolution of volatile products as shown in Figure 3. Further, heat treatment at temperature $350^{\circ} \mathrm{C}$ results into carbonization and more crystalline materials with silica encapsulated on the top of the char-like carbon materials (T4). This encapsulated silica becomes problematic when rice straw is used as fodder for animals. Also biocoals having higher content of silica can damage the reactor in the thermal power plant because of the abrasive nature of silica. Higher GCV is the most important property for biomass to be used as a fuel and it closely related to the proximate analysis $^{21}$.

Table 1 shows the proximate analysis, bulk density, GCV and energy yield of torrefied products at different torrefaction temperature experiments conducted in laboratory setup shown in Figure 1. Weight loss increases from $27 \%$ to $57 \%$ with increasing torrefaction temperature from $250{ }^{\circ} \mathrm{C}$ to $400^{\circ} \mathrm{C}$ while moisture content decreases from $9.44 \%$ to $4 \%$ and as a result of evolution of water, decomposition of hemicellulose, cellulose and lignin. On the other hand, volatile content decreases from $69 \%$ to $35 \%$ with increasing torrefaction temperature. With increasing torrefaction temperature, the fixed carbon content monotonically increases from $31 \%$ to $65 \%$. Increase in fixed carbon with increasing torrefaction temperature is due to the depletion of volatile matter. The maximum fixed carbon is at torrefied temperature $400^{\circ} \mathrm{C}$ because up to this temperature during torrefaction process maximum condensable and non-condensable volatiles are released. In this temperature range as discussed in earlier section, complete decomposition of hemicellulose and cellulose take place between $300^{\circ} \mathrm{C}$ and $350^{\circ} \mathrm{C}$. 

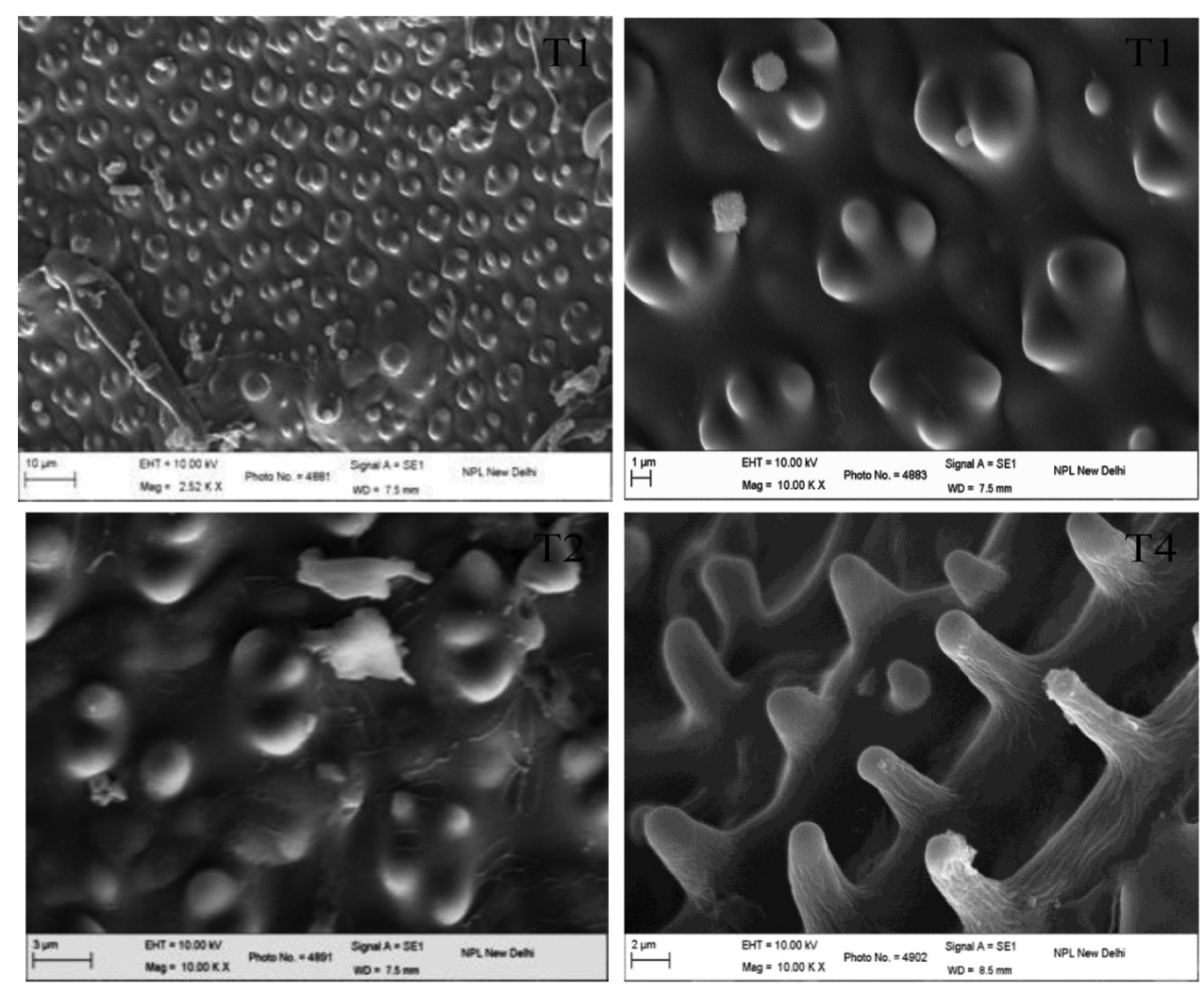

Figure 4. SEM images of (T1) raw rice straw and (T2 and T4) torrefied product.

Table 1. Proximate analysis, bulk density, gross calorific value and energy yield of torrefied products

\begin{tabular}{|c|c|c|c|c|c|c|c|c|}
\hline $\begin{array}{l}\text { Sample } \\
\text { code }\end{array}$ & $\begin{array}{l}\text { Weight } \\
\text { loss }(\%)\end{array}$ & $\begin{array}{c}\text { Moisture } \\
\text { content }(\%)\end{array}$ & $\begin{array}{c}\text { Volatile } \\
\text { content }(\%)\end{array}$ & $\begin{array}{c}\text { Fixed } \\
\text { carbon }(\%)\end{array}$ & $\begin{array}{l}\text { Bulk density } \\
\qquad(\mathrm{g} / \mathrm{cc})\end{array}$ & $\begin{array}{l}\text { Calorific value } \\
\text { (Kcal/kg) }\end{array}$ & $\begin{array}{c}\text { Mass yield } \\
(\%)\end{array}$ & $\begin{array}{c}\text { Energy yield } \\
(\%)\end{array}$ \\
\hline $\mathrm{T} 1$ & 0 & 9.44 & 69 & 31 & 0.22 & 3640 & - & - \\
\hline $\mathrm{T} 2$ & 27 & 3.88 & 65 & 35 & 0.396 & 3762 & 72.6 & 75 \\
\hline T3 & 42 & 2 & 60 & 40 & 0.532 & 4342 & 58.05 & 69 \\
\hline $\mathrm{T} 4$ & 54 & 0.65 & 44.5 & 55.5 & 0.562 & 5129 & 45.8 & 64 \\
\hline T5 & 57 & 0.4 & 35 & 65 & 0.558 & 5370 & 42.01 & 62 \\
\hline
\end{tabular}

Rice straw loses more oxygen and hydrogen than carbon during torrefaction process and as a result there is an increase in bulk density and GCV of torrefied products. The rice straw powder possesses $0.22 \mathrm{~g} / \mathrm{cc}$ bulk density which is measured by specific gravity bottle and it increases to $0.59 \mathrm{~g} / \mathrm{cc}$ after torrefaction at $400^{\circ} \mathrm{C}$. The $\mathrm{GCV}$ of raw rice straw powder is $3640 \mathrm{Kcal} / \mathrm{kg}$ and this value depends upon the extent of moisture content. On torrefaction at $250^{\circ} \mathrm{C}, \mathrm{GCV}$ is $3762 \mathrm{kcal} / \mathrm{kg}$ and it further increases to 4342,5129 and $5339 \mathrm{kcal} / \mathrm{kg}$ with increase in torrefaction temperature from $300^{\circ} \mathrm{C}$ to $400^{\circ} \mathrm{C}$. This continuous enhancement in GCV is due to loss of low energy content and increase in high energy content constituent such as fixed carbon.

The mass yield and energy yield are calculated from the following relations described by Bridgeman et al. ${ }^{14}$

$$
\text { Mass yield }(\%)=\frac{\text { Mass of torrefied products }}{\text { Mass of rice straw }} \times 100 \text {. }
$$

Energy yield $(\%)=$ Mass yield $\times$

Gross calorific value of torrefied products

$$
\text { Gross calorific value of rice straw }
$$

The energy yield decreases progressively from $75 \%$ to $62 \%$ with an increase in torrefaction temperature and is calculated from the relation between mass yield and GCV (eq. (2)). After torrefaction at $250^{\circ} \mathrm{C}, 75 \%$ energy is retained by torrefied products. With increase in the torrefaction temperature, i.e. $400^{\circ} \mathrm{C}$, energy yield decreases to $62 \%$. The mass yield of the torrefied products also decreases from $72 \%$ to $42 \%$ with increase in the torrefaction 
Table 2. Element composition and volume of rice straw and torrefied products

\begin{tabular}{|c|c|c|c|c|c|}
\hline \multicolumn{3}{|c|}{ Element composition (wt\%) } & \multicolumn{3}{|c|}{ Volume change $\left(\mathrm{cm}^{3}\right)$} \\
\hline Element (wt \%) & Rice straw & Torrefied product & Sample & As such & After grinding \\
\hline $\mathrm{C}$ & 23.23 & 48.52 & Rice straw & 7426 & 909 \\
\hline $\mathrm{Si}$ & 33.03 & 15.32 & Chopped rice (T1) & 3408 & 909 \\
\hline $\mathrm{O}$ & 43.18 & 34.25 & $\mathrm{~T} 2$ & 3099 & 505 \\
\hline K & 0.56 & 1.56 & T3 & 2919 & 375 \\
\hline $\mathrm{Mg}$ & 00 & 0.34 & $\mathrm{~T} 4$ & 2885 & 355 \\
\hline- & - & - & T5 & 2768 & 340 \\
\hline
\end{tabular}

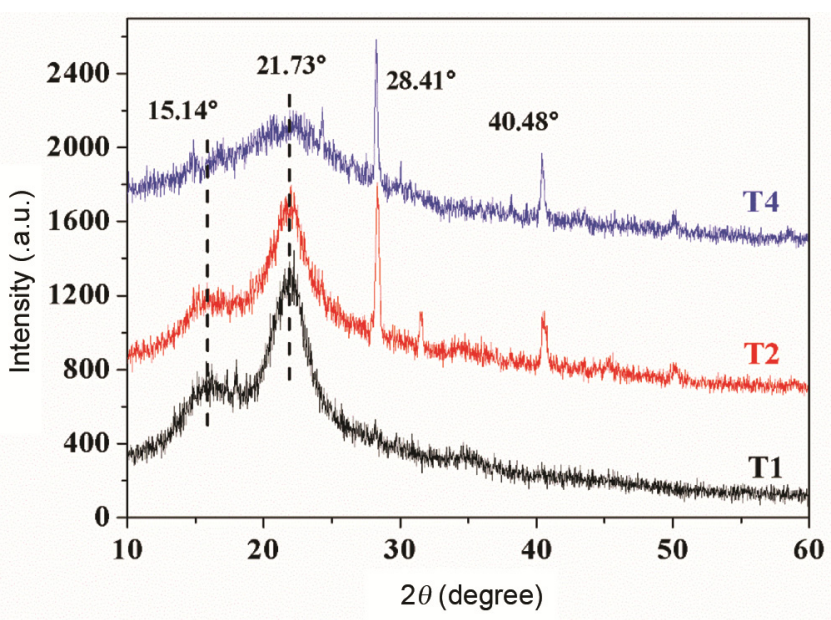

Figure 5. XRD plot of neat rice straw and torrefied rice straw at $250^{\circ} \mathrm{C}$ and $350^{\circ} \mathrm{C}$

temperature. There are two main causes for the decrease in mass yield of torrefied products: moisture loss and thermal decomposition of lignocellulose rice straw which forms volatile gaseous products.

Figure 5 depicts XRD plot of neat rice straw (T1) and torrefied products $\mathrm{T} 2$ and $\mathrm{T} 4$. It is observed that neat rice straw (T1) consists of two peaks at $2 \theta=15.14^{\circ}$, peak represents the plane of cellulose (110) and at $2 \theta=21.73^{\circ}$, peak represents the plane of polymeric cellulose (200) which corresponds to amorphous and crystalline regions. After torrefaction, peak at $2 \theta=15.14^{\circ}$ completely disappears (T4) due to the disintegration of cellulose structure. Also, peak intensity of cellulose (200) is decreased. However, after torrefaction at $250^{\circ} \mathrm{C}$ and $350^{\circ} \mathrm{C}(\mathrm{T} 2$ and T4), three peaks that evolve at $2 \theta=28.41^{\circ}$ and $40.48^{\circ}$ are that of $\mathrm{SiO}_{2}$. In neat rice straw silica is encapsulated in between cellulose, hemicellulose and lignin. However, due to the degradation of cellulose and hemicellulose above $200^{\circ} \mathrm{C}$, silica particles peak evolves. Above $300^{\circ} \mathrm{C}$, there is a decrease in the intensity of cellulose peak due to decomposition of cellulose and more clear evolution of silica. As a result, there is an increase in the intensity of $\mathrm{SiO}_{2}$ peak.

Table 2 shows the elemental analysis of rice straw and torrefied product at $350^{\circ} \mathrm{C}$. Rice straw contains
$23.23 \mathrm{wt} \%$ carbon, $33.03 \mathrm{wt} \%$ silica, $43.18 \mathrm{wt} \%$ oxygen, $0.56 \%$ potassium whereas after torrefaction, due to the degradation of lignocellulose's structure and volatilization, the carbon content increases to $48.52 \%$, while silica and oxygen content decrease to $15.32 \mathrm{wt} \%$ and $34.25 \mathrm{wt} \%$ respectively. The potassium content increases to $1.56 \%$ with an increment of magnesium. In case of rice straw, carbon, hydrogen, oxygen and silicon exist in various complex forms. As shown in Table 2, silicon content in the raw rice straw is $33 \mathrm{wt} \%$ and after torrefaction it decreases to $15 \mathrm{wt} \%$. During torrefaction $>300^{\circ} \mathrm{C}$, there is decomposition of hemicellulose and cellulose and pyrolysis of rice straw is initiated. This results in the destruction of rice straw cell structure which loses fibrous nature and becomes brittle. Due to the disintegration of straw structure, some of the silicon particles loosen and separate from torrefied straw structure.

Table 2 also shows volume change at different stages of torrefied biomass product before and after grinding. These values are representative of fixed weight of rice straw (200 g) initially and thereafter weight of torrefied products at successive torrefaction temperature. It is found that the rice straw itself occupied large volume, i.e. $7426 \mathrm{~cm}^{3}$, which is the major problem for transporting rice straw to the thermal power plant. After chopping the rice straw into $2 \mathrm{~cm}$ length, the volume decreases to $3408 \mathrm{~cm}^{3}$ and after torrefaction it further decreases by $66 \%$ and $75 \%$. The volume of torrefied biomass at $350^{\circ} \mathrm{C}$ is $2885 \mathrm{~cm}^{3}$. However, after grinding the torrefied product volume decreases significantly.

The volume of torrefied product decreases 7-8 times than that of raw rice straw. This can decrease the significant cost of transportation and solve the problem of biomass storage. For easy transportation of torrefied biomass, pelletization of torrefied product is an effective approach. However, torrefied product has negligible amount of moisture content and so it is difficult to make pellet from it. Therefore, some binder, like starch $(0.5-$ $1.0 \mathrm{wt} \%$ ), was used to make pellets in the laboratory through compression molding technique. Figure 6 shows that the pellets of different torrefied products possess $0.90 \mathrm{~g} / \mathrm{cc}$ bulk density. This value of density is equivalent to the value of bituminous coal used in thermal power plants as well as GVC, which is almost same. Thus use of 

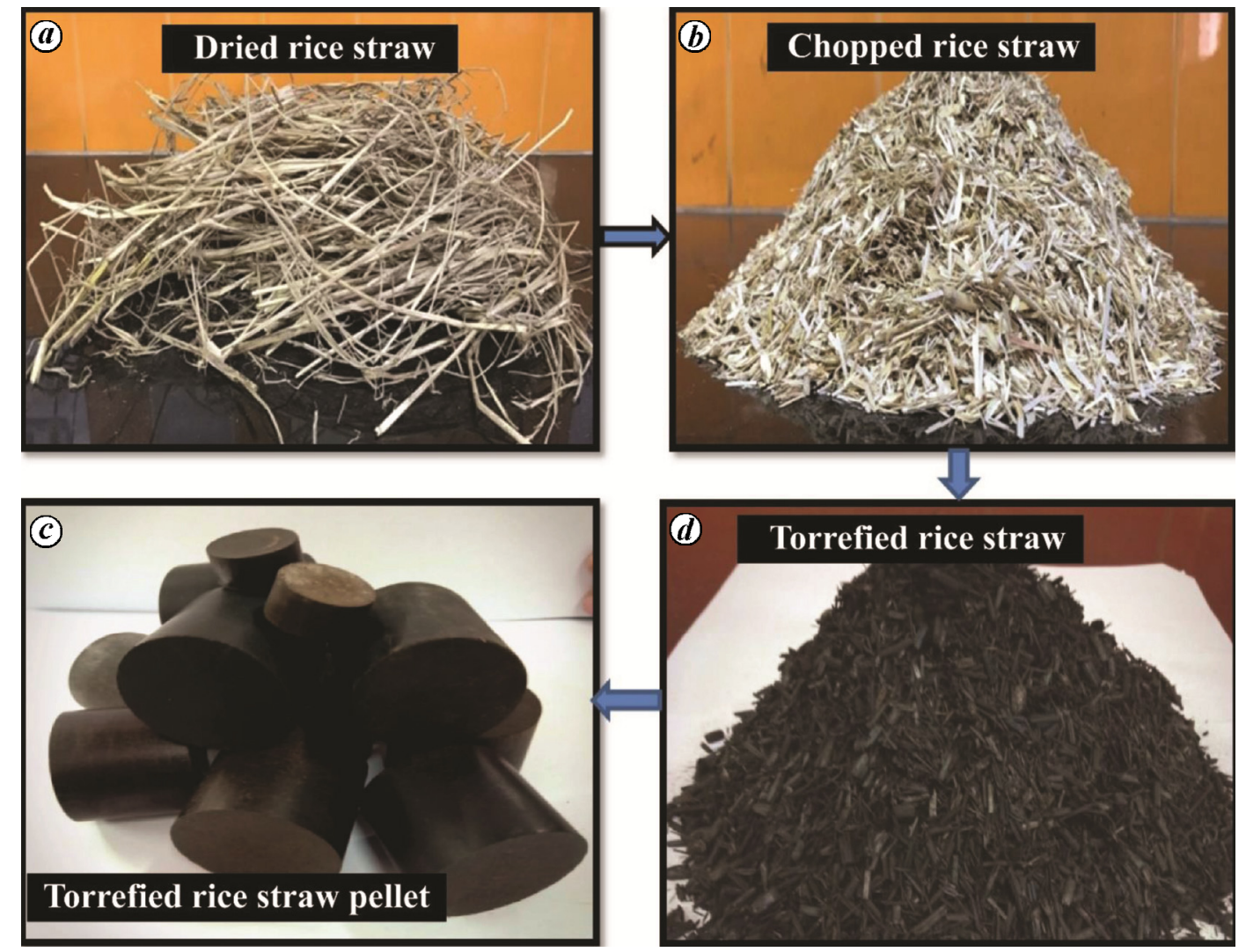

Figure 6. (a) Dried rice straw, (b) chopped rice straw, (c) torrefied rice straw product and (d) pellets from different torrefied products.

$10 \mathrm{wt} \%$ torrefied pellets with coal in thermal power plant requires 71.2 million tonnes of torrefied products. The yield of the torrefied material depends upon heating rate, torrefaction temperature and residual time. The yield of torrefied product prepared at torrefaction temperature of $300^{\circ} \mathrm{C}$ is about $50 \%-55 \%$ and 140 million tonnes rice can be converted into useful biomass using this process.

The present study was aimed to mitigate problems associated with rice straw burning in agriculture fields by farmers for sowing future crops which generally create environmental pollution. Torrefaction technique is used to make rice straw into useful biocoal for co-firing in thermal power plants. Torrefaction is carried out at temperature between $200^{\circ} \mathrm{C}$ and $450^{\circ} \mathrm{C}$ in protective atmosphere. It reveals that rice straw torrefied at $300^{\circ} \mathrm{C}$ has a yield of about $50-55 \%$ and an increase of GCV from $3640 \mathrm{kcal} / \mathrm{kg}$ to $4342 \mathrm{kcal} / \mathrm{kg}$ whereas fixed carbon content increases from $31 \%$ to $40 \%$ and density from $0.22 \mathrm{~g} / \mathrm{cc}$ to $0.50 \mathrm{~g} / \mathrm{cc}$. However, after densification/ pelletization bulk density reaches $0.90 \mathrm{~g} / \mathrm{cc}$ which is equivalent to density of bituminous coal. After torrefaction, the rice straw volume almost decreases by 7-8 times and attains hydrophobic nature. The torrefied product possesses comparative value of bulk density and GCV with that of bituminous coal which is used as energy source in thermal power plants. Use of $10 \mathrm{wt} \%$ torrefied product with coal required 71.2 million tonnes of torrefied rice straw. This in turn required $140 \mathrm{~m}$ tonnes of rice straw. Thus, if the problems associated with rice straw burning, its transportation and storage are solved, as a consequence, it not only reduces consumption of fossil fuels, but also reduces the environmental pollution and greenhouse emission. Unlike rice straw, residue of other crops like wheat, sugarcane, oilseed, maize and cotton available in India, is around 500 million tonnes. After torrefaction, these can also be used as biocoal for cofiring in thermal power plants.

1. Lim, J. S., Manan, Z. A., Alwi, S. R. W. and Hashim, H., A review on utilisation of biomass from rice industry as a source of renewable energy. Renew. Sust. Energ. Rev., 2012, 16, 30843094.

2. Singh, S. and Nain, L., Microorganisms in the conversion of agricultural wastes to compost. In Proceedings of the Indian National Science Academy, 2015, Spl. Sec. 80(2), pp. 473-481.

3. Dobermann, A. and Fairhurst, T., Rice straw management. Better Crop. Int., 2002, 16, 7-11.

4. Jeguirim, M. and Limousy, L., Biomass chars: elaboration, characterization and applications. Multidisciplinary Digital Publishing Institute.

5. Kadam, K. L., Forrest, L. H. and Jacobson, W. A., Rice straw as a lignocellulosic resource: collection, processing, transportation, and environmental aspects. Biomass Bioenerg., 2000, 18, 369389 . 
6. Sunyer, J., Urban air pollution and chronic obstructive pulmonary disease: a review. Eur. Respir. J., 2001, 17, 1024-1033.

7. Osamu, K. and Carl, H., Biomass Handbook, Gordon Breach Science Publisher, 1989.

8. Arias, B., Pevida, C., Fermoso, J., Plaza, M. G., Rubiera, F. and Pis, J., Influence of torrefaction on the grindability and reactivity of woody biomass. Fuel Process. Technol., 2008, 89, 169-175.

9. Evergreen Renewables, L., Biomass torrefaction as a preprocessing step for thermal conversion: reducing costs in the biomass supply chain. White Paper, 2009.

10. Bauen, A. et al., Bioenergy: a sustainable and reliable energy source. A review of status and prospects. A Report, IEA Bioenergy, 2009, pp. 1-108.

11. Sami, M., Annamalai, K. and Wooldridge, M., Co-firing of coal and biomass fuel blends. Prog. Energ. Combust. Sci., 2001, 27, $171-214$.

12. Liu, D., Zhang, C., Mi, T., Shen, B. and Feng, B., Reduction of n2o and no emissions by co-combustion of coal and biomass. J. Inst. Energ., 2002, 75, 81-84.

13. Abeberese, A. B., Electricity cost and firm performance: evidence from India. Rev. Econ. Stat., 2017, 99, 839-852.

14. Bridgeman, T., Jones, J., Shield, I. and Williams, P., Torrefaction of reed canary grass, wheat straw and willow to enhance solid fuel qualities and combustion properties. Fuel, 2008, 87, 844-856.

15. Ukaew, S., Schoenborn, J., Klemetsrud, B. and Shonnard, D. R., Effects of torrefaction temperature and acid pretreatment on the yield and quality of fast pyrolysis bio-oil from rice straw. J. Anal. Appl. Pyrol., 2018, 129, 112-122.

16. Bourgeois, J. and Doat, J., Torrefied wood from temperate and tropical species. Advantages and prospects. In Bioenergy 84th Proceedings of Conference, Goteborg, Sweden Volume III Biomass Conversion, Elsevier Applied Science Publishers, UK, 15-21 June 1984, pp. 153-159.

17. Chen, W.-H., Cheng, W.-Y., Lu, K.-M. and Huang, Y.-P., An evaluation on improvement of pulverized biomass property for solid fuel through torrefaction. Appl. Energ., 2011, 88, 36363644 .

18. Ciolkosz, D. and Wallace, R., A review of torrefaction for bioenergy feedstock production. Biofuel., Bioprod. Bioref., 2011, 5, 317-329.

19. Lu, K.-M., Lee, W.-J., Chen, W.-H. and Lin, T.-C., Thermogravimetric analysis and kinetics of co-pyrolysis of raw/torrefied wood and coal blends. Appl. Energ., 2013, 105, 5765.

20. Kongkaew, N., Pruksakit, W. and Patumsawad, S., Thermogravimetric kinetic analysis of the pyrolysis of rice straw. Energ. Proc., 2015, 79, 663-670.

21. Parikh, J., Channiwala, S. and Ghosal, G., A correlation for calculating hhv from proximate analysis of solid fuels. Fuel, 2005, 84, 487-494.

ACKNOWLEDGEMENT. The authors are grateful to Dr D. K. Aswal, Director, CSIR-NPL and Anil Kumar, Head, Advanced Materials and Device Metrology Division for their continuous encouragement and support.

Received 16 July 2018; revised accepted 15 November 2018

doi: $10.18520 / \mathrm{cs} / \mathrm{v} 116 / \mathrm{i} 5 / 831-838$

Nutrient composition, glucosinolate and vinyl-oxazolidine-thione profiling of Indian rapeseed (Brassica juncea Coss.) meal

\author{
M. S. Mahesh ${ }^{1,2, *}$, S. P. Tripathi ${ }^{1}$ and \\ Prashant M. Puri ${ }^{1}$ \\ ${ }^{1}$ Research and Development Centre (Animal Nutrition), \\ Indo Gulf Fertilisers, Jagdishpur, Amethi 227 817, India \\ ${ }^{2}$ Present address: Cargill Premix and Nutrition, Provimi Animal \\ Nutrition India Pvt. Ltd., IS-40, KHB Industrial Area, \\ Yelahanka New Town, Bengaluru 560 064, India
}

Presence of antinutritional factor(s) in any feedstuff impedes effective nutrient utilization by animals, besides causing specific adverse effects. This study includes eighteen different batches of Indian rapeseed (Brassica juncea Coss.) meal (RSM) sampled over a period of nine months for their evaluation in terms of nutrient composition, glucosinolate (GL) and vinyloxazolidine-thione (VOT) concentrations. Results showed that RSM contained a mean value (on dry basis) of crude protein $(36.7 \%)$, ether extract $(1.1 \%)$, ash $\mathbf{( 7 . 6 \% )}$, crude fibre $(\mathbf{1 0 \%})$, neutral detergent fibre $(\mathbf{2 5 \%})$, acid detergent fibre $(\mathbf{1 6 . 5 \%})$, hemicellulose $(8.6 \%)$, total carbohydrates $(54.7 \%)$, non-fibrous carbohydrates $(29.7 \%)$, total digestible nutrients $(\mathbf{7 7 . 9 \%})$ and metabolizable energy $(11.7 \mathrm{MJ} / \mathrm{kg})$. Furthermore, antinutritional factors like GL $(\mu \mathrm{mol} / \mathrm{g})$ and VOT $(\mathrm{mg} / \mathrm{g})$ are presented to be in the range of $36.2-72.2$ (mean: 52) and 0-3.2 (mean: 1.0) respectively. Based on the species-wise tolerance limit for GL, the optimum inclusion level of RSM recommended for ruminants, pigs, rabbits, rats, poultry and fish is $\mathbf{1 5 . 6 \%}$, $1.5 \%, 13.5 \%, 1 \%, 10.4 \%$ and $6.9 \%$ respectively. Results of the present study are expected to maximize precision ration balancing for enhanced nutrient utilization whilst also curtailing any possible adverse effects of GL and VOT on production performance of animals.

Keywords: Antinutrients, glucosinolates, NIRS, protein feeding, rapeseed meal.

RAPESEED or Indian mustard (Brassica juncea Coss.) is a popular oilseed crop and the meal/cake obtained after oil extraction is a customarily used protein source for livestock feeding. Its continuous availability with high quality in conjunction with its advantages as value for money and poor human-edible potential have made rapeseed meal (RSM) an attractive and well established component in many formulated compound animal feeds. Nutritionally, RSM is characterized by high crude protein (CP: $35-$ $40 \%$ ) with much $(\sim 65 \%)$ of rumen degradable fraction ${ }^{1,2}$, whilst its amino acid composition features a relatively rich methionine content ${ }^{3,4}$. On the other hand, RSM also

*For correspondence. (e-mail: drmaheshmsvet@gmail.com) 